\title{
Recenzje
}

DOI 10.14746/ssp.2020.4.7

\section{Levon Ter-Petrossian, Armenia Future, Relations with Turkey, and the Karabagh Conflict, edited by Arman Gri- goryan, Palgrave Macmillan, Cham 2018, ss. 174.}

Rozpad Związku Radzieckiego i pojawienie się na jego gruzach niepodległych państw jest nierozerwalnie związane z działalnością polityczną wyrazistych liderów republikańskich ruchów pierestrojkowych, którzy następnie odgrywali czołowe role w petryfikacji nowych bytów państwowych. Prawdą jest, że nie każda republika związkowa posiadała swojego Borysa Jelcyna, aczkolwiek sytuacja taka miała miejsce także na Kaukazie Południowym - w Gruzji, Armenii i Azerbejdżanie. Każda z tych republik miała na początku lat 90. charyzmatycznego przywódcę politycznego, który następnie obejmował urząd prezydenta. Byli to odpowiednio: Zwiad Gamsachurdia, Lewon Ter-Petrosjan i Abulfaz Elczybej. Wszyscy oni w okresie radzieckim byli dysydentami, natomiast ciekawym zrządzeniem losu wszyscy byli również naukowcami, filologami ze stopniami naukowymi. Losy każdego z wymienionych prezydentów potoczyły się zgoła odmiennie, lecz żaden z nich nie dotrwał do końca swojej kadencji: Z. Gamsachurdia zmarł w niejasnych okolicznościach, L. Ter-Petrosjan ustąpił $\mathrm{z}$ urzędu, zaś A. Elczybej został obalony w wyniku puczu. O ile prezydenci Gruzji i Azerbejdżanu postrzegani byli jako radykałowie nieliczący się z okolicznościami, prezydent Armenii był w swej działalności bardziej ostrożny i wyważony. Ich biografie są doskonałym świadectwem epoki, która coraz bardziej odchodzi w przeszłość, lecz wciąż zawiera wiele zagadnień wartych naukowego opracowania. Zwłaszcza w odniesieniu do przemian w niepodległej Armenii w polskim obrocie naukowym funkcjonuje niewiele prac, zaś luka ta jest stopniowo zasypywana (Czachor, 2014; Fedorowicz, 2017).

Recenzowana książka to zbiór publikacji i wystąpień L. Ter-Petrosjana, pierwszego prezydenta niepodległej Armenii, który stanowisko to zajmował w latach 1991-1998. Urodził się on w Syrii, następnie zamieszkał w ojczyźnie przodków, pracował naukowo w Erywaniu i podjął nielegalną działalność polityczną. Osobiście nie jest powiązany z Górskim Karabachem, co miało określone reperkusje dla jego kontaktów z „karabaskimi ludźmi”, gdy ci od połowy lat 90. zwiększali 
swoją obecność w polityce Armenii. Ustąpił z urzędu prezydenta przed końcem drugiej kadencji w związku z protestami, które wywołała jego propozycja podjęcia rozmów z władzami Azerbejdżanu na temat kompromisowego uregulowania kwestii Górskiego Karabachu oraz wola normalizacji stosunków z Turcją. Przez kolejną dekadę unikał on wystąpień publicznych, by w 2007 roku zgłosić się jako kandydat $\mathrm{w}$ wyborach prezydenckich. Powrót do polityki okazał się jednak nieudany. Obecnie L. Ter-Petrosjan ma 75 lat i stopniowo żegna się z aktywnym udziałem w życiu politycznym kraju. Wyboru tekstów zawartych w omawianej pracy dokonał Arman Grigorian, pracownik naukowy pensylwańskiego Lehigh University. Fakt ten oczywiście wpływa na obiektywizm książki, jednakże można ją potraktować jako cenne uzupełniające źródło wiedzy o pierwszych dekadach kształtowania się niepodległej Armenii. Jest to też swoista polemika L. Ter-Petrosjana z jego oponentami w kwestii ustroju Armenii, problemu Górskiego Karabachu i relacji międzynarodowych, szczególnie z Turcją i Azerbejdżanem. Publikacja jest tym bardziej godna odnotowania, że - dzięki wydaniu w języku angielskim - może ona dotrzeć do szerszego grona odbiorców. Niektóre zawarte w pracy teksty ukazały się wcześniej w zbiorze wystąpień i referatów L. Ter-Petrosjana wydanych $w$ języku ormiańskim (Ter-Petrosyan, 2007). Na zasadniczą część pracy składa się 7 rozdziałów, które dzielą się na mniejsze jednostki, będące fragmentami wystąpień, wywiadów, referatów byłego prezydenta.

Rozdział pierwszy Walka o zmiane logiki historii Armenii to wprowadzenie autorstwa A. Grigoriana. Zarysowuje on główne kierunki dyskursu politycznego w Armenii na przełomie lat 80 . i 90. oraz wskazuje na uproszczenia i niedopowiedzenia $\mathrm{w}$ badaniach zachodnich badaczy. Przede wszystkim wskazuje on, że ormiańska myśl narodowa posiadała (posiada nadal) niejedno imię, zaś pomiędzy zwolennikami historycznego „Dasznakcutjunu” a bardziej umiarkowanymi, „nowoczesnymi” działaczami narodowymi występują istotne różnice. Kluczowa w tym zakresie jest kwestia postrzegania stosunków ormiańsko-tureckich. Jak wskazuje A. Grigorian, funkcją tegoż postrzegania są stosunki ormiańsko-azerskie (bowiem przez część ormiańskiej doktryny Turcy i Azerowie nie są praktycznie rozróżniani, tworząc monolityczne, pantureckie zagrożenie dla Ormian) oraz kwestia karabaska, która przekracza wymiar sporu terytorialnego, stając się jednym z symboli konstytuujących współczesną martyrologię narodu ormiańskiego. Jak wskazuje badacz, wybrane przez niego teksty, tworzące treść kolejnych rozdziałów, pozwalają lepiej zrozumieć niuanse ormiańskiej polityki i tożsamości oraz różnego rozumienia przyszłości Armenii.

Okresowi poprzedzającemu uzyskanie pełnej niepodległości przez Armenię i wprowadzeniu urzędu prezydenta poświęcony jest drugi rozdział pracy - Wczesne wyzwania dla tradycyjnej narracji 1989-1991. Ostatnie wybory do parlamentu Armeńskiej SRR w 1990 roku przyniosły klęskę komunistom i zdobycie większości mandatów przez Ormiański Ruch Narodowy. Wskutek tego przewodniczącym Rady Najwyższej został niedawny dysydent L. Ter-Petrosjan 
i był to pierwszy taki przypadek na skalę Związku Radzieckiego. Rozdział ten zawiera wystąpienia L. Ter-Petrosjana na forum Rady Najwyższej Armeńskiej SRR, gdzie oponował bardziej radykalnym działaczom wzywającym do odbicia Górskiego Karabachu w imię walki Ormian z żywiołem tureckim. L. Ter-Petrosjan argumentował, że odwołanie do dziejowej sprawiedliwości i używanie retoryki nacjonalistycznej będzie przeciwskuteczne, zaś Ormianie winni dążyć do osiągnięcia swoich celów wyłącznie w drodze walki o przestrzeganie praw, które im jako ludności autonomicznej jednostki republiki związkowej ZSRR przysługują.

Kolejne dwa rozdziały: Relacje ormiańsko-tureckie po uzyskaniu niepodległości i dalsza walka oraz Konflikt karabaski i przyszłość państwa ormiańskiego to wybór tekstów i wystąpień L. Ter-Petrosjana, w których przedstawiał on priorytety swojej działalności na urzędzie głowy państwa oraz odrzucał krytykę swoich oponentów, którzy określali go mianem „turkofila” i „,rusofoba”. Prezydent argumentował, że w interesie Armenii - znajdującej się wówczas w stanie całkowitej blokady ze strony Turcji i Azerbejdżanu, gdzie powszechnie brakowało energii elektrycznej, paliwa, opału na zimę, a nawet żywności - jest ułożenie poprawnych relacji z najbliższymi sąsiadami. Wskazywał on, że w czasie walk o Górski Karabach do 1994 roku Armenia osiągnęła maksimum możliwości i pokojowe uregulowanie sporów w tym momencie jest najkorzystniejsze. L. Ter-Petrosjan argumentował, że Ormianie winni zerwać ze swoją naturą i syndromem ofiary czekającej na pomoc z zewnątrz. Winni siąść do stołu rozmów oddzielnie z Turcją i z Azerbejdżanem i nie oczekiwać na działania Rosji czy Stanów Zjednoczonych. W pierwszej połowie lat 90 . słowa takie brzmiały obrazoburczo i nie znajdowały zrozumienia wśród społeczeństwa. Szczególnie cenny jest artykuł Wojna czy pokój? Czas spoważnieć, który pierwotnie ukazał się na łamach ormiańskiej prasy 1 listopada 1997 roku. Prezydent argumentował, że upływ czasu gra na korzyść Turcji i Azerbejdżanu. Nawiązanie stosunków dyplomatycznych i otwarcie granicy z Turcją nie powinno być uzależniane od uznania przez Ankarę ludobójstwa Ormian. Armenia nie powinna torpedować procesu zbliżenia Turcji do Unii Europejskiej, gdyż ewentualna porażka w tej materii grozi zerwaniem z europeizacją i szybką radykalizacją tureckiej polityki, co przyniosłoby zagrożenie dla Armenii. Nieuregulowanie konfliktu z Azerbejdżanem w przyszłości może być fatalne w skutkach, bowiem państwo to szybko się bogaci i z czasem zyska zasoby, które mogą przesądzić o odbiciu z rąk Ormian spornego obszaru. Z perspektywy ponad dwóch dekad od wypowiedzenia tych słów ich słuszność i racjonalność działań L. Ter-Petrosjana nie budzi najmniejszych wątpliwości. Wówczas stały się impulsem do zajść, które skutkowały ustąpieniem prezydenta z urzędu i objęciem władzy przez jego najbardziej zdecydowanych oponentów - w tym Roberta Koczariana i innych „karabaskich ludzi”, których legitymizował niedawny triumf w wojnie o Arcach, jak Ormianie nazywają Górski Karabach.

Kolejny, piąty rozdział Poglady na konflikt karabaski i relacje ormiańsko-tureckie po powrocie do polityki zawiera fragmenty wystąpień i wywiadów 
L. Ter-Petrosjana po 2007 roku. Były prezydent przede wszystkim wskazywał na porażki okresu rządów R. Koczariana i Serża Sarkisjana, a więc klanu karabaskiego. Piętnował przede wszystkim jakikolwiek brak postępu w kwestii relacji bilateralnych z Turcją oraz z Azerbejdżanem. Wskazywał, że problemy pozostają te same, co w momencie jego rezygnacji z urzędu dekadę wcześniej, zaś Armenia posiada już zdecydowanie mniej argumentów na swoją korzyść. Twierdził, że rządy klanu karabaskiego, polegające przede wszystkim na utrzymaniu niepewności i status quo, były korzystne wyłącznie dla powiązanych z niedawnymi dowódcami grupami biznesowo-przestępczymi.

Wątki te są kontynuowane w kolejnych dwóch rozdziałach: Polityka $i$ geopolityka procesu normalizacji stosunków ormiańsko-tureckich oraz Dla pokoju $z$ sasiadami nie ma dobrej alternatywy. Zamieszczone w nich teksty sięgają do roku 2017. L. Ter-Petrosjan w przekonujący sposób argumentuje, że R. Koczarian i S. Sarkisjan w swojej niespójnej polityce względem dwóch najbardziej problematycznych sąsiadów sami wpędzili się w ślepy zaułek. Tak oceniał proces rozmów z Turcją w ramach tzw. „dyplomacji futbolowej”, gdy mecz piłkarski Armenia-Turcja stał się okazją, by do Erywania zaprosić prezydenta Abdullaha Güla. „Dyplomacja futbolowa” nie przyniosła oczekiwanych korzyści, przede wszystkim strona turecka nie otworzyła granicy, co z perspektywy gospodarki Armenii jest niezwykle pożądane. L. Ter-Petrosjan wskazywał, że ceną nieudanych rozmów z Turcją było uczynienie kwestii ludobójstwa Ormian kartą przetargową. Wynikało to $\mathrm{z}$ faktu, że jako element normalizacji relacji strona turecka przedstawiła propozycję powołania turecko-ormiańskiej komisji ds. wyjaśnienia kwestii ludobójstwa. L. Ter-Petrosjan wskazywał, że takim sposobem „karabascy ludzie" sprzeniewierzyli się ideałom, które sami głosili i dopuścili się gorszych błędów, niż te o które sami oskarżali byłego prezydenta w latach 90. Ostatnie umieszczone $\mathrm{w}$ zbiorze teksty są przepełnione rozgoryczeniem i bezsilnością. Były prezydent, oceniając geopolityczną sytuację Armenii, wskazywał na coraz trudniejsze perspektywy na przyszłość: wzmocnienie pozycji Azerbejdżanu, wyeliminowanie władz Górskiego Karabachu z procesu pokojowego, który mimo swoich oczywistych słabości prowadziła Grupa Mińska OBWE, a także coraz bardziej zdecydowaną politykę regionalną Turcji. Niezmiennie podkreślał, że jedynym rozwiązaniem, które zapewni Armenii bezpieczeństwo i rozwój to uregulowanie relacji z sąsiadami, które przez wszystkie strony będzie postrzegane jako satysfakcjonujące i nie będzie rodziło dążeń do kolejnych prób rewanżu.

Recenzowana praca jest bardzo cenna dla każdego badacza zajmującego się najnowszą historią Armenii. Przyda się zwłaszcza tym, którzy już zgłębiają tę tematykę i są w stanie skonfrontować treść książki z posiadaną wiedzą oraz odnieść ją do szerszego kontekstu. Po lekturze książki pozostaje także pewien niedosyt, którego jednak nie należy odnieść do samej publikacji. Chodzi o stwierdzenie określonych braków w badaniach politologicznych: do tej pory nie pojawiło się studium porównawcze przywództwa politycznego w kształtujących się po rozpadzie ZSRR nowych republikach (w tym zakresie sam Kaukaz Południowy do- 
starcza znakomitego materiału badawczego), nie ma także wyczerpującego studium ewolucji idei narodowej, czy to ormiańskiej, czy szerzej: państw Kaukazu Południowego po roku 1991. Są to frapujące zagadnienia, które warto zgłębić. Przedstawiona powyżej książka może być ku temu inspiracją.

\section{Bibliografia}

Czachor R. (red.) (2014), Armenia i Górski Karabach w procesach transformacji społecznej i politycznej, Instytut Polsko-Rosyjski, Wrocław.

Fedorowicz K. (2017), Transformacja ustrojowa w Armenii w latach 1991-2016, Instytut Wschodni UAM, Poznań.

Ter-Petrosyan L. (2007), Etrani, Printinfo, Erewan.

\section{Rafat CZACHOR}

Krakowska Akademia im. Andrzeja Frycza Modrzewskiego ORCID: 0000-0002-5929-9719 
